\title{
Analysis of Family Structure Influence on Academic Performance Among Secondary School Students in Bungoma East Sub-County, Kenya
}

\author{
Peter Barasa Nato \\ Faculty of Education, Department of Educational Leadership and Management, Mount Kenya University, Nairobi, Kenya
}

\section{Email address:}

peterbarasanato@gmail.com, peternato27@yahoo.com

\section{To cite this article:}

Peter Barasa Nato. Analysis of Family Structure Influence on Academic Performance Among Secondary School Students in Bungoma East Sub-County, Kenya. International Journal of Secondary Education. Vol. 4, No. 2, 2016, pp. 12-22. doi: 10.11648/j.ijsedu.20160402.11

Received: February 3, 2016; Accepted: March 31, 2016; Published: April 15, 2016

\begin{abstract}
A family is a fundamental unit in society. However, the structure of a family has been changing from the traditional family structure comprising of parents and their children to other forms of family structures that provides alternative dependence system. The emerging family structures may have an influence on academic performance in secondary schools' as students depend on the family emotional and material support. This study examined the influence of family structure influence on students' academic performance within Bungoma East Sub-County. The study objectives were to examine the Nuclear family structure influence on academic performance of students' public secondary schools in Bungoma East Sub-County; to examine the Single parent family structure influence on academic performance of students in public secondary schools in Bungoma East Sub-County. This study was guided by Bronfenbronner's principles of ecological theory of child on child development, a risk and protective model. Descriptive research design and mixed methodology was used to determine the extent to which variation in family structure and school setting influences students' academic performance. A sample size of 323 respondents was used in the study and a response rate of $95.7 \%$ was achieved. The questionnaire and interview schedule provided data that was analysed and presented findings through frequency tables, pie-charts, bar charts and others. Inferential statistics was used to analyse and ascertain relationship between family structure and academic performance. A regression analysis between family structure background and academic performance was performed and a Pearson Correlation test done to reveal significant correlation between the variables. The findings of this study revealed that good performance of learner with nuclear family was due to economic support, family support, parental motivation and home study environment. Nuclear family background positively influenced academic performance of student and it significantly accounted $16.7 \%$ variance in student performance. Single parent family background attributed good performance of learners with small percentage as shown by $92(30 \%)$. Single parent family background negatively influenced academic performance of student and it significantly explained 1.6\% variance in student performance. Policy makers should always take the subjective views of their wards into consideration in order to avert the problem of single parenthood, step parenthood and grandparenthood in the society. By doing so, the increase in nuclear family parenthood will provide socio-economic support and motivation needed for students to perform well in their academics. Boarding schools setup will reduce the parenting influence.
\end{abstract}

Keywords: Nuclear Family Structure, Single Family Structure, Academic Performance, Bungoma East

\section{Introduction}

Academic performance is a major goal in education thus it continues to interest educational researchers and practitioners alike (UNICEF, 2011). This implies that regularly, studies need to be conducted in order to find out factors that affect academic performance. However, performance in academics is vital but there exists a controversy in education as to what contributes to poor and good academic performance. According to Ngulat (2010) the ability of a learner to perform well in academics is often interested with various factors some usually beyond the control of the learner, for example, type of family structure and school factors. Findings on academic performance by Coleman reports that school factor differences have little impact on 
variation among individuals in terms of academic success (Chowa, Masa, Wretman and Ansong, 2012). This implies that the family and its structure contribute to a student's academic performance hence the researcher will try to find out how type of family structure influences student's academic performance in Bungoma County.

A study conducted in America by United Nations Children's Emergency Fund (UNICEF) (2011 Posited that the influence of type of family structure on academic success continue through high school. Moreover, types of family structure substantially influence outcomes such as high school dropout rates, graduation rates and age at first pregnancy. Besides, the most negatively affected type of family structure being non-intact as compared to intact families. Studies comparing the effects of family type on academic attainment in United States and Sweden yielded fascinating results. In both countries, children living in nonintact families had poor academic performance. The above mentioned studies in developed countries have an indication that type of family structure does not influence academic performance though the structure of the family may not directly influence academic performance but contextual factors like social economic status, parents educational level, and family assets/resources among others do influence students academic performance.

In Africa, the extended family is common, where groups of blood related people live together (Oyerinde, 2001). However, western culture has influenced the family in African, the rearing of children has moved from communal event to individualistic. This has led to different family structures in Africa such as single parent, step families. Wilcox et al. (2007) observed that children in intact, two parent households in developed countries. However, less is known about whether children living with biological two parents in the developing world have better academic performance than the children in stepfamilies or single parent family or children living in household without biological parents, with all things equal (Wilcox et al., 2007).

In Kenya, advert modernity, education, technology, urbanization, western influence and changing socioeconomic factors, the Kenyan society has increasingly become universal and ethnic identities and affiliations are fading (Xinhua, 2010). Family life has also changed with many families caught between the traditional family system that advocates for solidarity and the modern system which is characterized by individualism (Xinhua, 2010). Besides, The New Kenyan constitution (2010) in the fourth chapter on bills of rights may encourage transitions in the family leading to different types of family structures.

Although the Kenyan government has come up with policies such as free primary and secondary education to assist students to go through primary and secondary education, much lies on the family in terms of students' uniform, personal effects, pocket money and other necessities. This implies that Kenya like any other developing country, it's strained economically and cannot cater for all the expenses of a student. Therefore, the family has to come in and assist in one way or another towards students' education for better academic performance.

Many studies conducted in Kenya have been on comparing two family types (Grand parent family and Extended family), parenting style (Grace, 2001), father absence (Okero, 2004), home factors and their influence on academic performance (Akinyi, 2008) and less has been done on the influence of different family types on students' academic performance. In the current study, the researcher is interested in finding out whether different family types do influence students' academic performance in Bungoma East Sub-County, Kenya.

\subsection{Statement of the Problem}

Kenyan schools have been on the media of late on administrative and policy issues. The Cabinet Secretary has been in confrontation with the union and the industrial court at the centre of the conflict. Salaries and work conditions have been blamed for teachers' poor performance and general poor grades for students in some regions (Akinyi, 2008). Policy for education has also been at the centre of controversy as the cause. Bungoma East Sub-county has faced continued poor academic performance over some time. Studies have been done on the issue with focus on the school and education ministry as the cause of poor performance without consideration of the external environment to the school. The family of the learners cannot be wished out of the investigation for poor grades of learners. Besides, adolescence being one of the trying moments in one's life stages of development, preventing risks that may be brought about by the type of a family one grows in can greatly enhance this stage in life and help smooth transition to a successful and productive adulthood, (Xinhua, 2010).

From reviewed international literature, much of the studies on family structure and students' academic performance have compared both parent family and single parent family. Little is being done on the influence of different types of family structures that are coming up in the society and students academic performance, the researcher was therefore interested in finding out how type of family structure influence academic performance on secondary school students of Bungoma East Sub-County.

\subsection{Research Objectives}

The objectives of this study were:

1. To examine the Nuclear family structure influence on academic performance of students public secondary schools in Bungoma East Sub-County.

2. To examine the Single parent family structure influence on academic performance of students in public secondary schools in Bungoma East Sub-County.

\subsection{Nuclear Family}

This is a family with both parents (biological father and mother). It can also involve husband and wife and their adopted child/children. According to Michelle (2012) it is the traditional type of family and was held in esteem by society 
as being the ideal in which to raise children. Both parent are involved in training and upbringing of their child/children. Children in both parent family enjoy parental support financially, socially and physical help from their parents (Fagan \& Churchill, 2012). In addition, the environment is well stimulated and discipline is accorded promptly. Besides, there is a close parent-child relationship; children also enjoy good grandparent-grandchild relationship. In addition due to harmony and peace in the home, children do not leave home at early ages.

According to Wilcox, Whitney and Alejandro (2009) both parent family has several advantages: Two parent families typically have access to more employment, income, and savings and kin related economic resources than do single parent families (Amato, 2005), on average, two parents are able to devote more time, affection and monitoring to their children than are single parents (McLanahan \& Sendefor, 1994). Two parents can monitor one parenting style, as well as relieve one another when they find that parenting is becoming difficult. Consequently, the overall quality of parenting tends to be higher in two parent families, compared with single parent families. Two parents are typically more successful in involving both sets of a child's kin-based networks in providing social and emotional support to a child, compared with single parent families (Wilcox et al. 2009).

\subsection{Single Parent Family}

Single parent families can be defined as families where parent lives with dependent children, either or in a large household, without a spouse or partner. According to Michele (2012) and Ketteringham (2007), the single parent family is the biggest change society has seen in terms of changes in family structure. Some scholars argue that the family is breaking down (family- as defined to married couple residing with their dependent offspring) with negative effects for children, families and society (Popenoe, 1996). Other scholars have suggested that single parent families have been present in all societies overtime and should not be viewed as a deviant or problematic, but rather as an alternative family type (Coontz, 1997).

Regardless of how family diversity is viewed the increase in and prevalence of families headed by one parent has a major influence on the social economic and political context of family life (international Encyclopedia of marriage and family, 2003). According to Michele (2012) the highest percentage of single parent families are headed by women. It can be inferred that when one parent is at home, it may be a struggle to find child care as there is only one parent working. This limits income and opportunities in many cases, although many single parent families get help from relatives and friends.

In the developed countries, divorce has become more common thus they are experiencing an increase in single parent family. In the developing countries, divorce is not as common but desertion; death and imprisonment produce single parent families, primarily headed by women (Kinnear, 1999). In Kenya more than $25 \%$ of households are headed by women. Historically, single parent families were as a result of parental death, about one fourth of the children born around the turn of $19^{\text {th }}$ century experienced the death of a parent before they reached age 15 (Amato, 2000).

According to Ambert, children brought up by single parent by choice are at an advantage over those who fell into single parenting since their parents go into parenthood with their eyes open, well prepared financially and emotionally for the challenges of single parenthood (O'connel, 2007). The children are better because they have not experienced parental divorce and fighting as other children of single parents. The parents are also prepared in bringing up their children unlike in divorce, separation or even death.

\section{Research Design and Methodology}

\subsection{Research Design}

An ex post facto research design was adopted in conducted in this study. The design tries to compare two or more groups of individuals with similar backgrounds who are exposed to different conditions as a result of their natural histories (Lammers \& Badia, 2005).

The research methodology used was quantitative. According to Kothari (2006) quantitative research is based on measurement of quantity or amount. Moreover, quantitative research includes designs, techniques and measures that produce discreet numerical or quantitative data. This is to determine the extent to which variation in family type, gender and school setting influence students' academic performance.

\subsection{Sampling Procedures and Sample Size}

The researcher had a sample size of at least $30 \%$ of the students from the categories (rural and urban) in each district (504 students). The researcher also had 30\% representation of public schools from both sub-counties (21 schools) and 30\% representation of urban and rural schools (14 and 7 schools respectively).

The researcher used cluster sampling to select the schools and simple random sampling to select the students from different family types for the study. The researcher opted to use this method so as to improve the representatives of the sample by reducing the sampling error.

\subsection{Data Collection}

Through simple random sampling, the researcher selected the students to represent each family type. Thereafter the researcher held a brief meeting with the students; to explain the nature of the study and the protection of anonymity and confidentiality. The researcher gave personal motivational talk, and then distributed the questionnaires which were collected after one hour. The examinations' officer with the help of the Director of Studies will assist the researcher in getting the 2013 year academic performance in terms of actual total score of the respondents in three terms. 


\section{Data Analysis}

Various statistical techniques were applied in this process. In this study descriptive and inferential techniques were used. The data was coded and entered in the computer for analysis using the special package for social sciences (SPSS 20.0)

The biographical information was analyzed using multiple linear regression analysis and the t-test, and ANOVA was used to determine whether family type influences academic performance negatively or positively. The researcher was able to know whether the academic performance of the students from different family type differ significantly. Issues related to gender and difference in academic performance attracted the method which attempts to establish relationship between two variables that are categorical in nature, for example, ANOVA (Mugenda and Mugenda, 1999).

A two way ANOVA of 0.05 , level of significance was adopted. This was to determine whether there is a group of selected probability. Descriptive statistical involving the means, frequencies and percentage was used. These techniques do not warrant generalization of conclusions beyond the sample(s) under observation. The researcher finding were presented in frequency distribution, percentages and charts.

\section{Research Findings and Discussion}

\subsection{Demographic Characteristics of the Respondents}

This section discusses the social and demographic characteristics of the surveyed sample population; these include school setting, gender, family structure and class for the students' respondents. Out of the 323 questionnaires that were administered, 309 were returned and met minimum entry condition for further analysis in this study. This represented approximately $95.67 \%$ of the total questionnaires administered. The researcher considered this response rate as satisfactory to continue with analysis. Those who did not respond to the questionnaire were 14 who cited their work schedules as the impediment for data collection exercise.

Figure 4.1 below shows that Teachers were 20.1\%(62) while students were $79.9 \%(247)$.

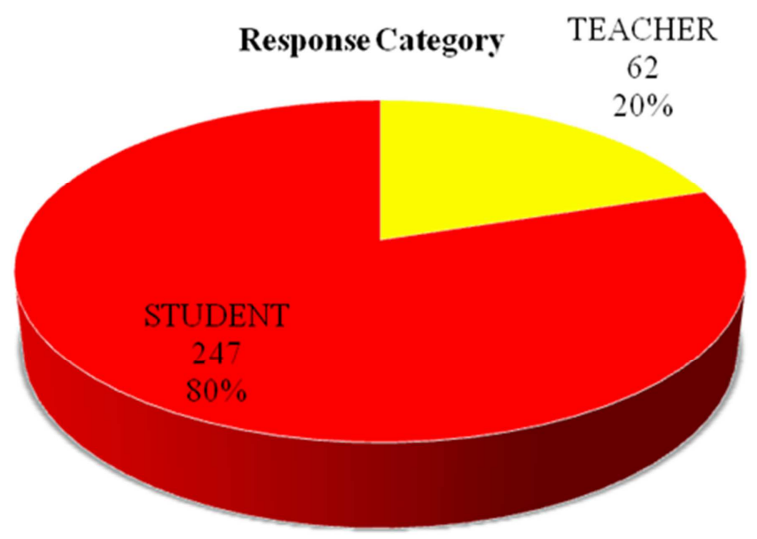

Figure 4.1. Response Category.
This response rate was as desired since the students population is much higher than teachers and students were expected to give primary opinion of their experience with family structure.

\subsubsection{School Setting of the Respondents}

The respondents were required to state their school setting as either urban or rural school. Rural schools were majority as they were $65 \%(201)$ while urban schools were $35 \%(108)$. This was expected because Bungoma East sub county is rural located. This revealed that many schools are located far away from urban areas which give the student ample time for concentration on their study for better performance. The results are as shown in Figure 4.2.

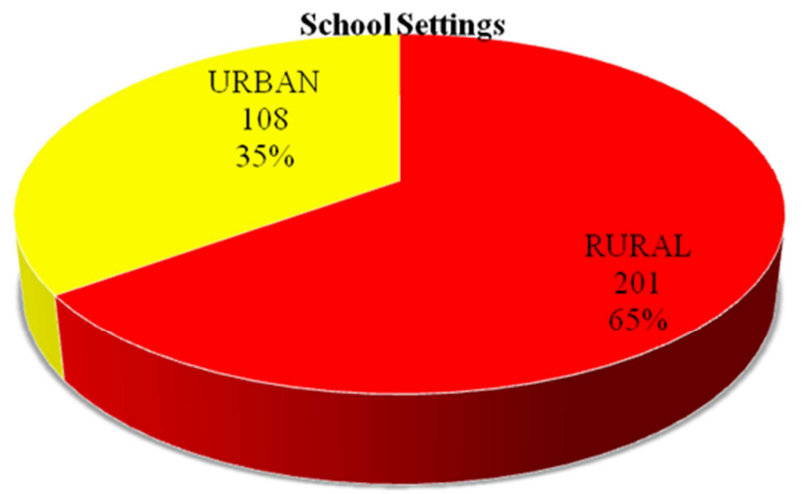

Figure 4.2. Shows the School setting of the respondents as being rural or urban.

\subsubsection{Gender of the Respondents}

The respondents were required to state their gender. The valid gender was female and male. Male respondents were majority as they were $66 \%(204)$ while female were $34(105)$. This revealed that majority of respondents students and teachers are male as compared to female in Bungoma East County. This was acceptable because though most teachers are female, the students are boys in majority accounting for high male respondents in returned questionnaires. The results are as shown in Figure 4.3.

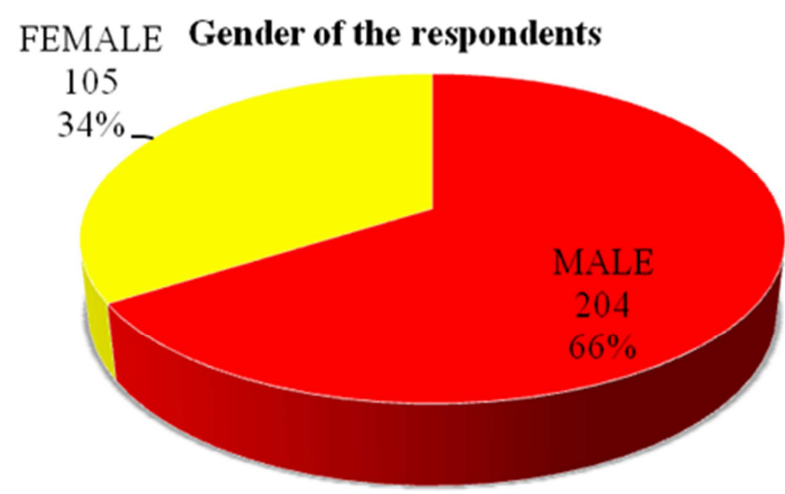

Figure 4.3. Above shows Gender of the respondents.

\subsubsection{Students' Class of the Respondents}

The students' respondents were asked their current academic class. Form one students were 19.02\%(47) while 
form two students were $20.65 \%(51)$. Form three students were majority and they formed $33.6 \%(83)$ and $26.72 \%(66)$ of the respondents were form four.The results revealed that majority of students respondents were in form three as the form four students were preparing for Final examination (KCSE). This was acceptable as the researcher purposively targeted form threes as experienced adolescents to give views on family structure. The results below show student's class of the respondents in Figure 4.4.

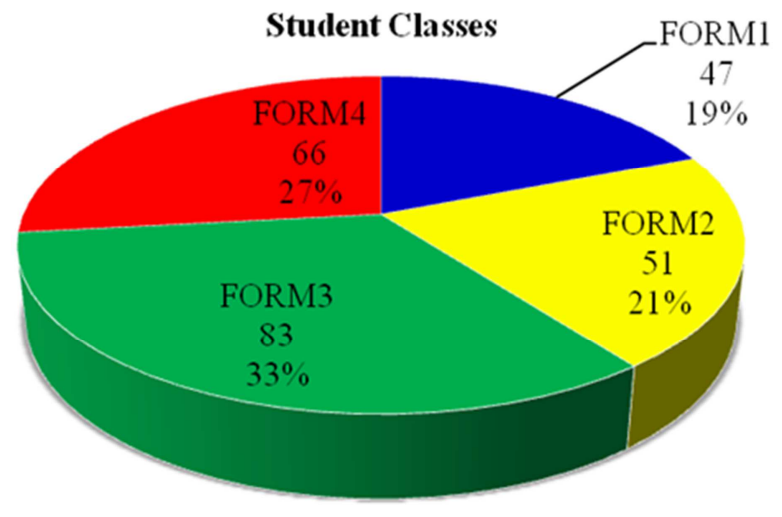

Figure 4.4. Student class of the respondents.

\subsubsection{The Students' Family Structure of the Respondents}

The students' respondents were asked their family structure. Nuclear family was majority as they comprised $37.9 \%(117)$ of the respondents. They were followed by single $22.3 \%(69)$. In this setting, Nuclear family is still valued and the majority of the respondents are from that family. Single parent family and family were found to be more common in the urban setting and came second.

\subsection{Analysis of Objective One: Nuclear Family Structure Influence on Academic Performance}

The first objective of the study was to examine the Single parent family structure influence on academic performance of students in public secondary schools in Bungoma East SubCounty. The objective answered the first research question of the study "Does the nuclear family structure influence academic performance of students' public secondary schools in Bungoma East Sub-County?" This was done through examining economic support, family support, parental motivation and home study environment of nuclear family in relation to KNEC mean score, mock results, class rank and homework completion. Both teachers and students were issued with set of statement. The analysis was done by using both descriptive and inferential statistics. The inferential was used to examine the influence of nuclear family on student academic performance. The results are as follows.

\subsubsection{Nuclear Family Descriptive Results}

The sampled teachers and students were required to respond to four statements relating to nuclear family in terms of economic support, family support, parental motivation and home study environment. The pertinent results are presented in Table 4.1.

Table 4.1. Nuclear Family Response.

\begin{tabular}{|c|c|c|c|c|c|c|c|}
\hline Nuclear Family & SD & D & UD & $\mathbf{A}$ & $\mathbf{S A}$ & Mean & SD \\
\hline $\begin{array}{l}\text { Students from nuclear family have family economic support } \\
\text { that positively affect the school KNEC Mean score }\end{array}$ & $11(3.56)$ & $18(5.83)$ & $22(7.12)$ & $177(57.28)$ & $81(26.21)$ & 4.22 & 1.17 \\
\hline $\begin{array}{l}\text { Students from nuclear family have family support that } \\
\text { positively affect their mock Results }\end{array}$ & $6(1.94)$ & $10(3.24)$ & $30(9.71)$ & $102(33.01)$ & $161(52.1)$ & 4.21 & 1.09 \\
\hline $\begin{array}{l}\text { Students from nuclear family have parental motivation that } \\
\text { positively affect their Class position/Rank }\end{array}$ & $6(1.94)$ & $10(3.24)$ & $21(6.8)$ & $83(26.86)$ & $189(61.17)$ & 4.36 & 1.03 \\
\hline $\begin{array}{l}\text { Students from nuclear family have home study environment } \\
\text { that positively affect their homework completion }\end{array}$ & $8(2.59)$ & $26(8.41)$ & $35(11.33)$ & $172(55.66)$ & $68(22.01)$ & 4.05 & 1.34 \\
\hline \multirow{2}{*}{ Summary } & Mean & S.E & SD & Skewness & \multicolumn{3}{|c|}{ Kurtosis } \\
\hline & 4.00 & .05154 & .90595 & -.761 & \multicolumn{3}{|c|}{.484} \\
\hline
\end{tabular}

Table 4.1, economic support with a mean of 4(Agree) and standard deviation of 1.17 revealed that $83.49 \%$ of the respondent confirmed that Students from nuclear family have family economic support that positively affects the school KNEC Mean score of which 177(57.28\%) of the agreed with economic support from nuclear family positively affected performance. Nuclear family support with a mean of 4(Agree) and standard deviation of 1.09 indicated that $85.11 \%$ of the respondent confirmed that Students from nuclear family have family support that positively affects their mock Results with majority of them 161(52.1\%) of them strongly agreeing that nuclear family support positively affect the performance of student.

Similarly, nuclear parental motivation with a mean of 4 (Agree) and standard deviation of 1.03 revealed that $88.03 \%$ of the respondent confirmed that Students from nuclear family have parental motivation that positively affect their Class position/Rank with more than half of total respondents $189(61.17 \%)$ of them strongly agreeing that parental support from nuclear family positively affected academic performance. Lastly, home study environment with a mean of 4(Agree) and standard deviation of 1.34 revealed that $77.67 \%$ of the respondents confirmed that Students from nuclear family have home study environment that positively affect their homework completion of which $172(55.66 \%)$ of them agreed that home study environment positively affected academic performance of students.

Overall, nuclear family with a mean of 4.00(Agree) with a minimal standard error of 0.052 and standard deviation of 0.91 indicated that majority of the respondents agreed that 
nuclear family structure positively affected academic performance of the students in Public secondary schools in Bungoma East Sub County. The distribution was negatively skewed further indicating that majority of the response was on the right of the mean (4) and the peakedness was leptokurtic indicating that majority of the response were around the mean (Agree).

The respondents were also asked "In your opinion, do you attribute good academic performance of learners with nuclear". Of the total respondents, 263(85\%) of them agreed that good academic performance was as a result of learners with nuclear family structure. The significant association of these results was tested statistically using choice square of association so as to find if there is statistically significant association between the family structure and the opinion. The findings are presented in Table 4.2.

\section{Good academic performance of learners with nuclear family background}

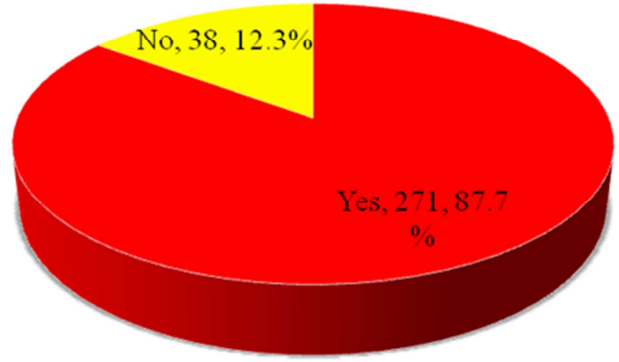

Figure 4.5. Opinion on Nuclear family and good academic performance.

\subsubsection{Dichotomous Results of the Opinion of Nuclear Family Between Students and Teachers}

The significant association of these results was tested statistically using chi square of association so as to find if there is statistically significant association between the respondents and the opinion on nuclear parent family on student academic performance. The findings are presented in Table 4.2.

Table 4.2. Nuclear Family Results

\begin{tabular}{lllll}
\hline \multirow{2}{*}{$\begin{array}{l}\text { Opinion on } \\
\text { Nuclear Family }\end{array}$} & \multicolumn{2}{l}{ Response Category } & Total \\
\cline { 3 - 4 } & & Teacher & Student & \\
\hline \multirow{2}{*}{ Yes } & $\mathrm{a}$ & $19.6 \%$ & 218 & 271 \\
& $\mathrm{~b}$ & $85.5 \%$ & $80.4 \%$ & $100.0 \%$ \\
& & 9 & $88.3 \%$ & $87.7 \%$ \\
No & $\mathrm{a}$ & $23.7 \%$ & 29 & 38 \\
& $\mathrm{~b}$ & $14.5 \%$ & $76.3 \%$ & $100.0 \%$ \\
& & 62 & $11.7 \%$ & $12.3 \%$ \\
Total & $\mathrm{a}$ & $20.1 \%$ & 247 & 309 \\
& $\mathrm{~b}$ & $100.0 \%$ & $79.9 \%$ & $100.0 \%$ \\
\hline
\end{tabular}

Note. $\mathrm{X}^{2}(1, \mathrm{~N}=309)=.354, \mathrm{p}=0.342$, Cramer's $\mathrm{V}=0.034$; ${ }^{\mathrm{a}}=$ row percentages; $\mathrm{b}=$ column percentages; Cramer's V: weak association $<=0.20$, moderate association $<=0.20-0.49$, strong association $>0.49$
From Table 4.2 , of the $87.7 \%$ of the respondents who had opinion that learners from nuclear family had good academic performance, $85.5 \%$ of teachers had that opinion while $88.3 \%$ of students also had opinion that nuclear family structure was responsible for good academic performance. With $\chi^{2}(1, \mathrm{~N}=309)=0.354, \mathrm{p}=0.342$ and Cramer's $\mathrm{V}=$ 0.034 indicated there was not significant variation between the teachers and students in good academic performance that is attributed by the nuclear family structure.

\subsubsection{Influence of Nuclear Family Structure on Academic Performance of Students}

Inferential statistics which included Pearson correlation and simple linear regression analysis were used to find the significant influence of Nuclear Family structure. The Pearson correlation established the strength, direction and significant of the influence with $\mathrm{R}$ of $95.0 \%$ confidence level while regression determine the influence of nuclear family structure on student academic performance using R Square. The relevant results are presented in Table 4.3.

Table 4.3. Results of Nuclear Family.

\begin{tabular}{|c|c|c|c|c|c|c|c|}
\hline \multicolumn{3}{|c|}{ Pearson Correlation } & \multicolumn{5}{|c|}{ Model Summary } \\
\hline $\mathrm{R}$ & \multicolumn{2}{|c|}{ Sig. (2-tailed) } & $\begin{array}{ll}\mathrm{R} & \\
\text { Square } & \mathrm{I}\end{array}$ & $\begin{array}{l}\text { Adjusted } \\
\mathrm{R}^{2}\end{array}$ & df & $\mathrm{F}$ & $\begin{array}{l}\text { Sig } \\
\text { Value }\end{array}$ \\
\hline $.408^{* *}$ & .00 & & .167 & .164 & 1,308 & 61.440 & $.000^{\mathrm{b}}$ \\
\hline \multicolumn{8}{|c|}{ Regression Coefficients } \\
\hline \multirow{2}{*}{\multicolumn{2}{|c|}{ Model }} & \multicolumn{2}{|c|}{$\begin{array}{l}\text { Unstandardized } \\
\text { Coefficients }\end{array}$} & \multicolumn{2}{|c|}{$\begin{array}{l}\text { Standardized } \\
\text { Coefficients }\end{array}$} & $\mathrm{t}$ & Sig. \\
\hline & & B & Std. Error & Beta & & & \\
\hline \multicolumn{2}{|c|}{ (Constant) } & 1.290 & .275 & & & 4.696 & .000 \\
\hline \multicolumn{2}{|c|}{ NUCLEAR } & .597 & .076 & .408 & & 7.838 & .000 \\
\hline
\end{tabular}

a. Dependent Variable: PERFORMANCE

a. Predictors: (Constant), NUCLEAR

Table 4.3 reveals a significant good positive relationship between nuclear family structure and academic performance of students with $\mathrm{R}=0.408 * *, \mathrm{P}<0.05$ with $99.0 \%$ confidence level as obtained from Pearson correlation analysis. This implies that nuclear families structure has significant positive influence on the academic performance of the student. Since Correlation indicated that nuclear family has positive influence on academic performance of study, linear regression analysis revealed that the findings established that $16.7 \%$ variation in student academic performance is significantly explained by nuclear family structure leaving $83.3 \%$ to be explained by other factors with $\mathrm{F}(1,308)=61.440, \mathrm{P}<0.05$ as obtained from $\mathrm{R}$ square value of 0.167 . The regression coefficients revealed that an increase or decrease of nuclear family structure by one unit would result to a significant change in student academic performance by 0.597 with $\mathrm{t}=7.838, \mathrm{P}<0.05$

\subsubsection{Discussion on Objective One Findings}

The first objective of the study sought to examine the Nuclear family structure influence on academic performance of students' public secondary schools in Bungoma East Sub- 
County. The findings of this objective aimed to answer to the nuclear family structure influence academic performance of students' public secondary schools in Bungoma East SubCounty. Majority of the respondents $(83.49 \%)$ indicated that students from nuclear family have economic support that positively affects the school KNEC Mean score. Similar results were revealed by $85.11 \%$ of the respondent who also revealed that from nuclear family have family supports that positively affect their mock Results.

Nuclear family has parental motivation that positively affects Class position/Rank of students and the home study environment positively affect student homework completion as shown by $88.03 \%$ and $77.67 \%$ respectively. Overall, majority of the respondents agreed (Mean=4, S.E=0.052) that nuclear family attributed to good performance of learner. There was no significant variation on the opinion of students and teacher with $\chi^{2}(1, \mathrm{~N}=309)=0.354, \mathrm{p}=0.342$ that $87.7 \%$ of them had opinion that good performance of students is as a result of nuclear family.

The relationship between nuclear family structure and academic performance was good and positive (with $\mathrm{R}=0.408^{* *}, \mathrm{P}<0.05$ ) at $95.0 \%$ confidence level signifying that it has a significant positive influence on the academic performance of the student. Simple linear regression analysis established that $16.7 \%$ variation in student academic performance is significantly explained by nuclear family structure leaving $83.3 \%$ to be explained by other factors with $\mathrm{F}(1,308)=61.440, \mathrm{P}<0.05$.

It was further noted that good academic performance in nuclear family is as a result of no external interference that in most cases has caused unnecessary disruption in completion of homework as the structure offers friendly environment. The parents were found to offer moral, holistic and basic support as well as motivating their children to excel in their academics. Also both parents are concerned with academic progress of their children as they are close to children thereby understanding their strength and weakness in academic performance. Children in both parent family enjoy parental support financially, socially and physical help from their parents (Fagan \& Churchill, 2012). According to Wilcox, Whitney and Alejandro (2009) both parent family has several advantages: Two parent families typically have access to more employment, income, and savings and kin related economic resources than do single parent families (Amato, 2005), on average, two parents are able to devote more time, affection and monitoring to their children than are single parents (McLanahan \& Sendefor, 1994).

\subsection{Single Parent Family Structure Influence on Academic Performance}

The second objective of the study was to examine the Single parent family structure influence on academic performance of students in public secondary schools in Bungoma East Sub-County. The objective answered the second research question of the study "Does Single parent family structure influence academic performance of students in public secondary schools in Bungoma East Sub-County?" This was done through examining economic support, family support, parental motivation and home study environment of single parent family in relation to KNEC mean score, mock results, class rank and homework completion. Both teachers and students were issued with set of four statements. The analysis was done by using both descriptive and inferential statistics. The inferential was used to examine the influence of single parent family on student academic performance. The results are as follows.

\subsubsection{Single Parent Family Descriptive Results}

The sampled teachers and students were required to respond to four statements relating to single parent family in terms of economic support, family support, parental motivation and home study environment. The relevant results are presented in Table 4.4.

Table 4.4. Single Parent Family Response.

\begin{tabular}{|c|c|c|c|c|c|c|c|}
\hline Single Parent Family & SD & D & UD & $\mathbf{A}$ & SA & Mean & SD \\
\hline \multirow{4}{*}{$\begin{array}{l}\text { Students from Single parent family have family economic } \\
\text { support that positively affect the school KNEC Mean score } \\
\text { Students from Single parent family have family support that } \\
\text { positively affect their mock Results } \\
\text { Students from Single parent family have parental motivation } \\
\text { that positively affect their Class position/Rank } \\
\text { Students from Single parent family have home study } \\
\text { environment that positively affect their homework completion }\end{array}$} & $\begin{array}{l}59 \\
(19.09)\end{array}$ & $182(58.9)$ & $\begin{array}{l}33 \\
(10.68)\end{array}$ & $24(7.77)$ & $11(3.56)$ & 2.18 & 0.95 \\
\hline & $28(9.06)$ & $62(20.06)$ & $\begin{array}{l}159 \\
(51.46)\end{array}$ & $41(13.27)$ & $19(6.15)$ & 2.87 & 0.96 \\
\hline & $34(11)$ & $167(54.05)$ & $\begin{array}{l}46 \\
(14.89)\end{array}$ & $33(10.68)$ & $29(9.39)$ & 2.43 & 1.12 \\
\hline & $\begin{array}{l}187 \\
(60.52)\end{array}$ & $54(17.48)$ & $\begin{array}{l}33 \\
(10.68)\end{array}$ & $23(7.44)$ & $12(3.88)$ & 1.77 & 1.14 \\
\hline \multirow{2}{*}{ Summary } & Mean & S.E & $\mathrm{SD}$ & Skewness & & Kurtosis & \\
\hline & 2.7055 & .06549 & 1.15123 & .016 & & -.766 & \\
\hline
\end{tabular}

From Table 4.4, family economic supports with a mean of 2(Disagree) and standard deviation of 0.95 revealed that $77.99 \%$ of the respondents did not confirmed that Students from Single parent family have family economic support that positively affect the school KNEC Mean score with $182(58.9 \%)$ of them strongly disagree. Family support with a mean if 3(undecided) and standard deviation of 0.96 indicated that $159(51.46)$ of the respondents were undecided whether Students from Single parent family have family support that positively affect their mock Results. However, $29.12 \%$ of them confirmed that it affected mock results negatively while $19.42 \%$ confirmed that it affected mock 
results positively.

It was further noted that parental motivation of the single parents affected rank of student negatively with a mean of 2(Disagree) and standard deviation of 0.96 . The results indicated that $34(11 \%)$ and $167(54.05 \%)$ of the respondents strongly disagree and disagree respectively that Students from Single parent family have parental motivation that positively affect their Class position/Rank. Lastly, home study environment with a mean of 2(Disagree) and standard deviation 1.14 revealed that $78 \%$ of the respondents did confirm that Students from Single parent family have home study environment that negatively affect their homework completion with $187(60.52 \%)$ of them strongly agree that it does affect negatively.

With an overall mean of 3(undecided) with standard error of 0.065 and standard deviation of 1.151, the findings revealed that majority of the respondent were undecided with single parent positively affecting student academic performance. The distribution was positively skewed to indicating that majority of the response were on the left side of mean which shows that most of them did not confirm that it affected academic performance positively though the mean was 3(undecided) as shown by the platykurtic peakedness of the distribution.

The respondents were also asked "In your opinion, do you attribute good academic performance of learners with Single parent family background?" Of the total respondents, $217(70 \%)$ of them did not confirmed that good academic performance was as a result of learners with single parent family structure while only $30 \%$ of them attribute it to single parent family structure. The findings are presented in Figure 4.6.

\section{Good academic performance of learners with} Single family background

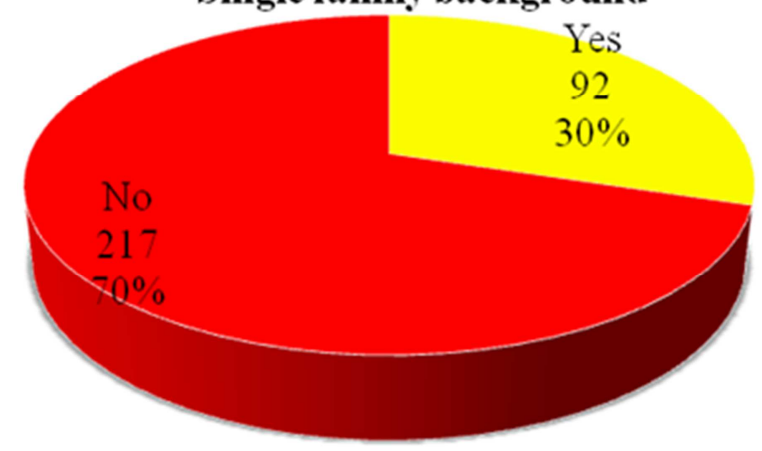

Figure 4.6. Opinion on Single parent family and good academic performance.

\subsubsection{Dichotomous Results of the Opinion of Single Parent Family}

The significant association of these results was tested statistically using choice square of association so as to find if there is statistically significant association between the family structure and the opinion on single parent family on student academic performance.

The findings are presented in Table 4.5.
Table 4.5. Results on Single Parent family

\begin{tabular}{|c|c|c|c|c|}
\hline \multirow{2}{*}{\multicolumn{2}{|c|}{$\begin{array}{l}\text { Opinion on } \\
\text { Single family }\end{array}$}} & \multicolumn{2}{|c|}{ Response Category } & \multirow{2}{*}{ Total } \\
\hline & & Teacher & Student & \\
\hline \multirow{3}{*}{ Yes } & & 7 & 85 & 92 \\
\hline & a & $7.6 \%$ & $92.4 \%$ & $100.0 \%$ \\
\hline & $\mathrm{b}$ & $11.3 \%$ & $34.4 \%$ & $29.8 \%$ \\
\hline \multirow{3}{*}{ No } & & 55 & 162 & 217 \\
\hline & a & $25.3 \%$ & $74.7 \%$ & $100.0 \%$ \\
\hline & $\mathrm{b}$ & $88.7 \%$ & $65.6 \%$ & $70.2 \%$ \\
\hline \multirow{3}{*}{ Total } & & 62 & 247 & 309 \\
\hline & a & $20.1 \%$ & $79.9 \%$ & $100.0 \%$ \\
\hline & $\mathrm{b}$ & $100.0 \%$ & $100.0 \%$ & $100.0 \%$ \\
\hline
\end{tabular}

Note. $\mathrm{X}^{2}(1, \mathrm{~N}=309)=12.673, \mathrm{P}=0.000$, Cramer's $\mathrm{V}=0.203 ; \quad \mathrm{a}=$ row percentages; ${ }^{b}=$ column percentages; Cramer's V: weak association $<=0.20$, moderate association $<=0.20-0.49$, strong association $>0.49$

From Table 4.5 , of the $70.2 \%$ of the respondents who had opinion that learners from singleparent family did not have good academic performance, $88.7 \%$ of teachers had that opinion while $65.6 \%$ of students had same opinion. With $\chi^{2}$ $(1, \mathrm{~N}=309)=12.673, \mathrm{p}=0.000$ and Cramer's $\mathrm{V}=$ 0.203 indicated there was significant moderate variation between the teachers and students response in academic performance that is attributed by the single parent family structure.

\subsubsection{Influence of Single Parent Family Structure on Academic Performance of Students}

Inferential statistics which included Pearson correlation and simple linear regression analysis were used to find the significant influence of single parent Family structure in student academic performance. The Pearson correlation established the strength, direction and significant of the influence with R of $95.0 \%$ confidence level while regression determine the influence of single parent family structure on student academic performance using R Square.

The relevant results are presented in Table 4.6.

Table 4.6. Results on Single Parent Family

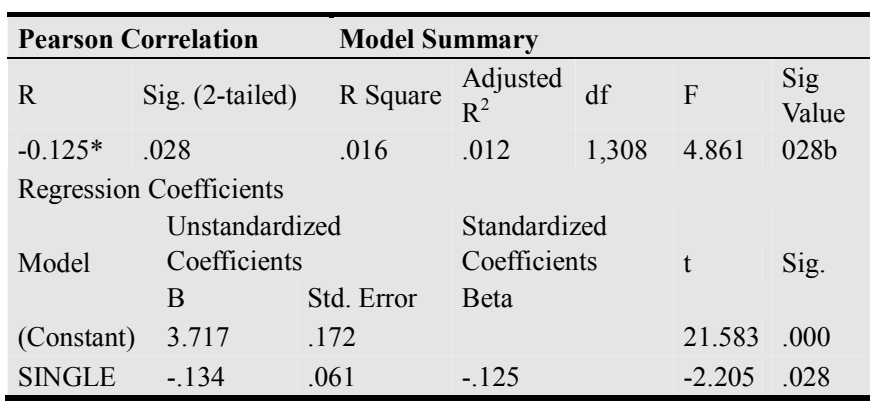

a. Dependent Variable: PERFORMANCE

a. Predictors: (Constant), Single Parent

Table 4.6 reveals significant weak inverse relationship between single parent family structure and academic performance of students with $\mathrm{R}=-0.125^{*}, \mathrm{P}<0.05$ at $95.0 \%$ confidence level as obtained from Pearson correlation analysis. This implies that single parent familystructure has weak significant negative influence on the academic 
performance of the student. Since Correlation analysis indicated that nuclear family has negative influence on academic performance of student, linear regression analysis further revealed that with $\mathrm{R}$ square of 0.016 established that $1.6 \%$ variation in student academic performance is significantly explained by single parent family structure leaving $98.4 \%$ to be explained by other factors with $\mathrm{F}(1,308)=4.861, \mathrm{P}<0.05$. The regression coefficients revealed that an increase or decrease of single parent family structure by one unit would result to an significant change in student academic performance by 0.134 with $\mathrm{t}=-2.205, \mathrm{P}<0.05$.

\subsubsection{Discussion on Objective Two Findings}

The second objective of the study sought to examine the Single parent family structure influence on academic performance of students in public secondary schools in Bungoma East Sub-County. The findings of this objective aimed to answer Single parent family structure influence academic performance of students in public secondary schools in Bungoma East Sub-County. Minority of the respondents $(11.33 \%)$ indicated that students from single parent family have economic support that positively affects the school KNEC Mean score. Similar results were obtained from $19.42 \%$ of the respondent who also revealed that from single parents' family have family supports that positively affect their mock Results.

Single parents' family has average parental motivation that positively affects Class position/Rank of students and the home study environment positively affect student homework completion as shown by $34.96 \%$ and $11.32 \%$ respectively. Overall, majority of the respondents were undecided (Mean=3, S.E=0.065) that single parent family attributed to good performance of learner. There was significant variation on the opinion of students and teacher with $\chi^{2}(1, \mathrm{~N}=309)=$ $12.673, p=0.000$ that $70.2 \%$ of them had opinion that good performance of students is not as a result of single parent family.

The relationship between single family structure and academic performance was weak and negative $(\mathrm{R}=-0.125 *$, $\mathrm{P}<0.05$ ) at $95.0 \%$ confidence level signifying that it has a significant negative weak influence on the academic performance of the student. Simple linear regression analysis revealed that $1.6 \%$ variation in student academic performance is significantly explained by single parent family structure leaving $98.4 \%$ to be explained by other factors with $\mathrm{F}(1,308)=4.861, \mathrm{P}<0.05$.

Teachers hinted that bad performance is attributed to over protection of the student by the single parents especially the mothers. This makes the students to be reluctant as most of the parents are too soft on their children general performance. Lack of both parental love was identified by both students and teachers. Other factors attributing to bad performance were lack of holistic support, limited family resources to support education and social challenges. It was further noted that single parents have a lot of work to do and generate income for the family survival and in most cases they left the children on their own especially in doing of their homework which affected their academic negatively. In some single families, children are forced to work for income so that they support their family or they are given a lot of work at home.

Lack of gender figure especially for girls leave then with trauma for lack of love from both parents and motivation which is found in nuclear family thereby affecting their academic performance. According to Michele (2012) the highest percentage of single parent families are headed by women. It can be inferred that when one parent is at home, it may be a struggle to find child care as there is only one parent working. This limits income and opportunities in many cases, although many single parent families get help from relatives and friends.

However, some single parents especially mothers encourage and challenge their children to perform well which results to good performance from nuclear family. According to Ambert, children brought up by single parent by choice are at an advantage over those who fell into single parenting since their parents go into parenthood with their eyes open, well prepared financially and emotionally for the challenges of single parenthood (O'connel, 2007). The children are better because they have not experienced parental divorce and fighting as other children of single parents. The parents are also prepared in bringing up their children unlike in divorce, separation or even death. Independent $t$ test was used to analysis the hypotheses. In analyzing the first hypothesis, its showed that there is no significant difference between the academic performance of children from single-parent homes and those from two parent homes.

The above result shows that children from single parent can still be serious and attain a high academic level depending on the capability of such a single parent. The researchers' view is supported by Scepter and Prensky (2009), which said that the extent to which the child's intellectual potentialities for success in educative processes can be realized depend initially on how the parents who transmitted these potentialities can provide and sustain them.

\section{Summary, Conclusion and Recommendations}

\subsection{Summary of Findings}

The study focused on analyzing of family structure influence on academic performance among secondary school students in Bungoma east sub-county, Kenya. The independent variable was family structure under dimension of nuclear and single parent. The academic performance of student which was defined by KNEC KCSE mean score, mock results, class rank and homework completion formed dependent variable. Contextual factors like school management, school infrastructure, staffing and school culture formed intervening variable.

The findings of this study revealed that most of the respondents $271(87.1 \%)$ attributed good performance of learner with nuclear family background which offered economic support, family support, parental motivation and 
home study environment. Nuclear family background positively influenced academic performance of student and it significantly accounted $16.7 \%$ variance in student performance. Single parent family background attributed good performance of learners with small percentage as shown by $92(30 \%)$. However majority of the respondents $(70 \%)$ indicated lack of economic family support and home study environment negatively affected student academic performance. Single parent family background negatively influenced academic performance of student and it significantly explained $1.6 \%$ variance in student performance.

\subsection{Conclusion}

Based on the findings, the following conclusion were made in relation to research questions. The results of this study provided evidence that nuclear family background positively influenced academic performance of students in public secondary schools. However, single parent, negatively influenced academic performance of students in public secondary schools. However, the results confirmed that single parent family lacked family economic support that influenced academic performance of the students in public secondary school.

\subsection{Recommendations}

After discussing the findings of the research, certain recommendations are put forward for consideration. The research findings and interpretation reveal that measures need to be taken to ensure that the academic performance of schools in Bungoma East Sub county increases as far family structure is concerned.

Studies have shown that when families are involved in their children's education, children earn higher grades and receive higher scores on tests, attend school more regularly, complete more homework, demonstrate more positive attitudes and behaviors in that connection the government should initiate educative and enlightenment programme on how to improve and sustain intact parenthood through the radio, television and other mass media.

Parents, guardian and care giver must be encouraged to participate in their children's education. They have the distinct advantage over anyone else in that they can provide a more stable and continuously positive influence that could enhance and complement what the school fosters on their children. In this regard, parental involvement is undeniably critical. A disconnect between them and the educational learning experiences of their children result in the child's behavioral problems at school, stress in accomplishing one's responsibilities and weakness in academic performance. Parental involvement in their children's education and having a positive attitude including carrying out learning activities in the home and transforming the home setting into an educational context, improves the academic attainment of the child and influences quality education. Also, involvement with respect to participating in school functions, buying necessary school equipment (books, uniforms) is important.

Management plays a critical role in shaping the institutions of learning. Management in learning institutions requires very strong decision making skills. School boards should be composed of members who possess managerial skills, expertise and experience. Power and decision-making should be shared among the members responsibly. Teamwork and team development promotes a shared understanding and common goal within the learning institution. When the principal treats all the teachers and workers as colleagues who are in the school for the common good of the school, then the shared vision will be achieved. There should be teamwork among all the stakeholders with each willing and ready to perform his duties and responsibilities.

Education support infrastructure plays a critical role in the enhancement of the learning process. Ideal situation, a teaching institution should have a large and adequate reception area for visitors, an office block with all administrative facilities, computer facilities, telephone system, adequate classrooms to accommodate all classrooms, specialist rooms and adequate laboratories that that are well equipped, comfortable dormitories for the learners to rest, toilets and bathrooms, computer laboratories and playing fields that facilitates co-curricular activities. Lack of adequate facilities affects the participation and overall performance of a student. The school stakeholders should ensure that adequate and sufficient infrastructure and learning materials are always available. In case of shortages, the teachers should make good use of what is available as they wait for more supply of facilities. This will ensure that there is no total loss on the student.

Policy makers should always take the subjective views of their wards into consideration in order to avert the problem of single parenthood, step parenthood and grandparenthood in the society. By doing so, the increase in nuclear family parenthood will provide socio-economic support and motivation needed for students to perform well in their academics.

\section{References}

[1] Amato, P. (2000). The consequences of divorce for adults and children. Journal of marriage and the family, 62; 1268-1287.

[2] Akinyi, P. (1993). Children's adjustment to divorce: Theories and hypotheses and empirical support. Journal of marriage and the family, $55 ; 23-38$.

[3] Amato, P. (2001). Children of divorce in the 1990's: An update of the Amato \& Keith (1991). Meta- analysis. Journal of family psychology, 15; 355-370.

[4] Amato, P. R., (2005). The impact of family formation change on the cognitive, social and emotional well being of the next generation. The future of children, 15; 75-96.

[5] Akinyi, P. A. (2008). The influence of parenthood on academic achievement motivation among secondary school students. A case of siaya district Kenya Unpublished thesis Moi University, Eldoret, Kenya. 
[6] Chowa B., N. (2012). The concept of family Demographic and Genealogical perspectives. Journal sociation today. 2.2. The North Carolina Sociological Association ISSN 1542-6300.

[7] Coontz, P., (1997). Influence of gender on academic achievement. Michigan, University of Michigan.

[8] Grace, S., (2001). The effects of family structure on educational attainment. Do the effects vary by age of the child? (Electronic version) American Journal of Economics and Sociology, 54(1); 89-105.

[9] Hetherington, E., Hernderson, S. \& Reiss, D. (1999) Adolescent siblings in step families: family functioning and adolescent adjustment, monograph of the society for the study of child development, 259 (4) 64.

[10] International Encyclopaedia. \& Kellys J. (2007). For better or worse. New York: Norton.

[11] Ketteringham, M. (2007). Parenting in divorced and remarried families, in M. Bornstein (ed) Handbook of parenting: 3: Being and becoming a parent, Lawrence Eribaum Associates, Mauwah, NJ.

[12] Kothari, E. (2006). Hostility, hostile detachment, and conflict engagement in marriages: Effects on child and family functioning. Child development, 73; 636-651.

[13] Lammers, W. J, \& Badia P. (2005). Fundamental of behavior Research. Califonia: Thomson and Wadsworth.

[14] Mc Lanahan, S. S., \& Sandefur, G. (1994). Growing up with a single parent: what hurts? What helps? Cambridge, MA: Harvard University Press.

[15] Michelle, B. (2012). Types of family structure, Afro introduction. Com/marriage.

[16] Minuchin, P. (2002). "Looking towards the Horizon: Present and future in the study of family systems", in MCHale and W. Grolnick (eds) Retrsospect and prospect in the psychological study of families, Lawrence Eribaum Associates, London.
[17] Muleyi, W. G. (2008). Effects of Home factors and type of school on academic performance of girls in secondary school in Bungoma district. Unpublished thesis Moi University, Eldoret, Kenya.

[18] Mugenda, O. M. \& Mugenda, A. G. (2003). Research Methods. Nairobi: Acts Press.

[19] Ngulat, T. (2004). Impact of HIV/AIDS on Generational roles and intergenerational relationships. Nigeria.

[20] O'connel, D. (2007). Single parenting by choice Family life parenting strategies Canada. Com. 2005-2012.

[21] UNICEF (2011). Family background and literacy performance http://www.oecd.org/dataoecd/33/9/336905591.

[22] Okero, B. O. (2004). The influence of father absence on locus of control and academic performance among secondary school students, A study of Kisii central district. Unpublished thesis Moi, University Eldoret, Kenya.

[23] Oyerinde, O. (2001). The impact of family structure, Parenting practices and family size on children's academic performance. Nigeria school.

[24] Popenoe, K. (1996). Children in changing families' life after parental separation, Blackwell publishers, Oxford United Kingdom.

[25] Scepter and Presnisky (2009). Co-parenting family process and family structure: implications for prescholers externalizing behavior problems, journal of family psychology, 15.3; 526-545.

[26] Wilcox, B., L., Whitney and Alejandro, (2009). Making The Grade. Family structure and children educational participation in Colombia, Egypt, India, Kenya, Nigeria, Peru and Uruguay. http:mpra.ub.uni.muenchen-39905.

[27] Xinhua, R. (2010). Kenya modern family, Coast week. Com/3525/30.h.t.m. Nairobi. 